\title{
The quantification and role of diffuse myocardial fibrosis in familial dilated cardiomyopathy - an equilibrium contrast cmr study
}

\author{
Daniel M Sado*, Andrew S Flett, Christopher M Cook, Caroline J Coats, Giovanni Quarta, Jonathan M Hasleton, \\ Derek J Hausenloy, Perry M Elliott, James C Moon
}

From 2011 SCMR/Euro CMR Joint Scientific Sessions

Nice, France. 3-6 February 2011

\section{Objective}

To evaluate the role of diffuse myocardial fibrosis (DMF) in familial Dilated Cardiomyopathy (fDCM) using Equilibrium Contrast-CMR (EQ-CMR).

\section{Background}

Post mortem/biopsy studies have shown that DMF occurs in DCM, but its clinical significance remains largely unknown as its assessment requires invasive biopsy. EQ-CMR is a recently described technique that permits the non-invasive and accurate assessment of DMF by measuring the myocardial contrast volume of distribution $(\mathrm{Vd}(\mathrm{m}))$ at equilibrium contrast [1].

\section{Methods}

Using international diagnostic guidelines we identified 28 patients with fDCM (mean age 42, 61\% male, 89\% NYHA class I, $11 \%$ NYHA class II). This cohort excluded the most severe cases of fDCM due to the high prevalence of permanent pacemakers or ICDs.

The $\mathrm{Vd}(\mathrm{m})$ (a measure of DMF) was compared to that obtained in healthy volunteers (mean age 35, 63\% male) and also to other indexed CMR parameters, including left atrial area and echocardiographic parameters of diastolic function (tissue doppler and strain imaging).

\section{Results}

fDCM patients had increased LV size $(95 \mathrm{mls} / \mathrm{m} 2$ vs $73 \mathrm{mls} / \mathrm{m} 2, \mathrm{p}=0.0001)$, worse ejection fraction $(55 \%$ vs

The Heart Hospital, London, UK
$69 \%, \mathrm{p}<0.0001$ ), increased indexed left atrial area (LAAi) $(12.3 \mathrm{~cm} 2 / \mathrm{m} 2$ vs $9.5 \mathrm{~cm} 2 / \mathrm{m} 2, \mathrm{p}=0.0004)$ when compared to healthy volunteers. Significantly impaired diastolic function was detected in $14 \%$ of fDCM patients. No patients had worse than mild mitral regurgitation.

The $\mathrm{Vd}(\mathrm{m})$ in patients was significantly greater than that of healthy volunteers (Fig 1) (0.282 vs 0.234 , $\mathrm{p}=0.003) . \mathrm{Vd}(\mathrm{m})$ correlated with LAAi (fig 2$)(\mathrm{r} 2=0.44$, $\mathrm{p}<0.0001)$ and $\mathrm{EF}(\mathrm{r} 2=0.12, \mathrm{p}=0.034)$, but was independent of indexed LV diastolic volume, mass and echocardiographic derived parameters of diastolic function.

On univariate analysis, LAAi was predicted by both $\mathrm{Vd}(\mathrm{m})(\mathrm{r} 2=0.44)$ and $\mathrm{E} / \mathrm{Ea}(\mathrm{r} 2=0.31)$, which on multivariate analysis were independent with $\mathrm{Vd}(\mathrm{m})$ being the strongest predictor.

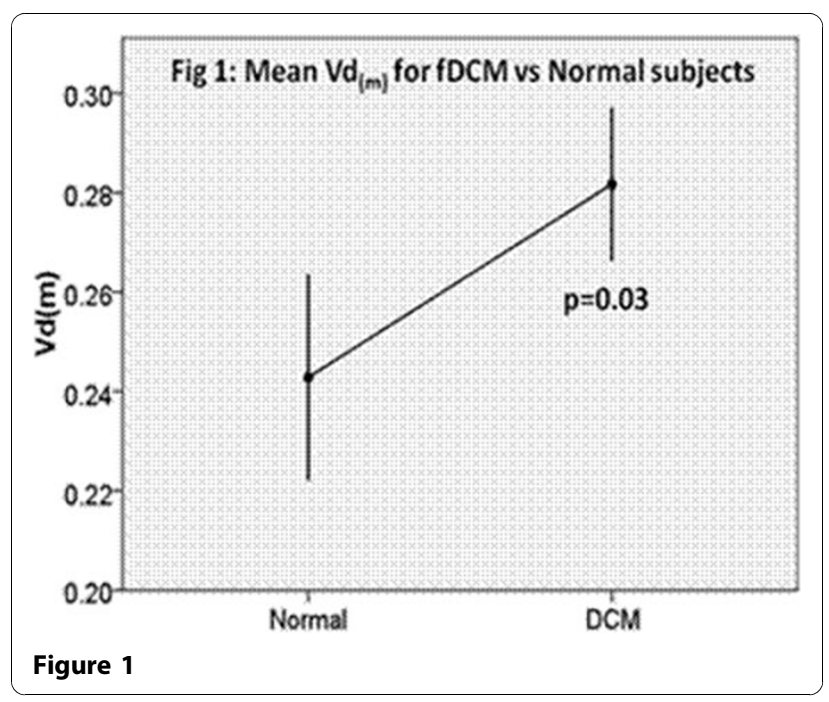

(c) 2011 Sado et al; licensee BioMed Central Ltd. This is an open access article distributed under the terms of the Creative Commons :HWed Central Attribution License (http://creativecommons.org/licenses/by/2.0), which permits unrestricted use, distribution, and reproduction in any medium, provided the original work is properly cited. 


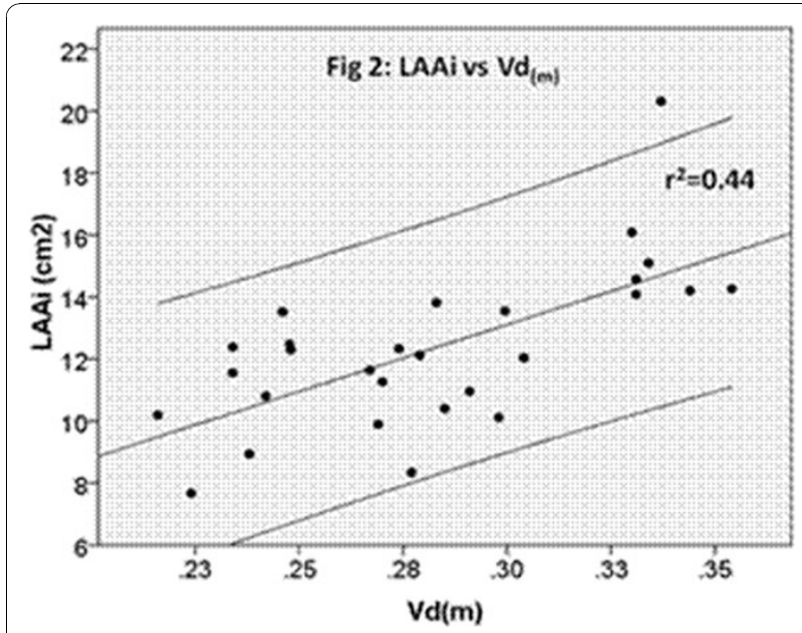

Figure 2

\section{Conclusion}

EQ-CMR can reliably and non-invasively measure increased $\mathrm{Vd}(\mathrm{m})$, reflecting DMF even in patients with mild fDCM. Diffuse myocardial fibrosis in this tightly defined fDCM cohort correlates with known prognostic variables, particularly LA size and EF. For LA size, DMF is independent of diastolic function and the most important predictor. As such, these data suggest EQ-CMR is measuring a key disease parameter. Further study is recommended.

Published: 2 February 2011

\section{Reference}

1. Circulation. 2010, 122(2):138-144.

doi:10.1186/1532-429X-13-S1-0108

Cite this article as: Sado et al:: The quantification and role of diffuse myocardial fibrosis in familial dilated cardiomyopathy - an equilibrium contrast cmr study. Journal of Cardiovascular Magnetic Resonance 201113 (Suppl 1):0108.

Submit your next manuscript to BioMed Central and take full advantage of:

- Convenient online submission

- Thorough peer review

- No space constraints or color figure charges

- Immediate publication on acceptance

- Inclusion in PubMed, CAS, Scopus and Google Scholar

- Research which is freely available for redistribution 